\title{
Factors Related to Family Planning Acceptor Participation in the Sumulagung Village Community, Cikunir Village, Tasikmalaya Regency in 2019
}

\author{
$1^{\text {st }}$ Annisa Rahmidini \\ Lecturer of Midwifery Program Study \\ STIKes Respati \\ Singaparna Street KM 11 Cikunir \\ Tasikmalaya, West Java Indonesia. \\ annisarahmidini@gmail.com
}

\author{
$2^{\text {nd }}$ Chanty Yunie Hartiningrum \\ Lecturer of Midwifery Program Study \\ STIKes Respati \\ Singaparna Street KM 11 Cikunir \\ Tasikmalaya, West Java Indonesia
}

\begin{abstract}
Strategies to increase the degree kesehat late mother in order to achieve an Indicator Sustainable Development Goals (SDGs) is a way to reduce maternal mortality up to 70 / 100,000 live births, one efforts to be made by expanding family planning is participation. To know the factors associated with participation in family planning acceptors $\mathbf{m}$ asyarakat Kampung Sumulagung Village Cikunir Tasikmalaya District 2019. Quantitative researchcross sectional approach, using instruments in the form of questionnaires and SEM data analysis . The number of samples was 49 women of childbearing age, with a purposive sampling technique. Based on the results of the analysis above, it is known that the analysis of factors related to the participation of $K B$ acceptors obtained an $R^{2}$ value of 0.956 meaning that all factors analyzed could explain the participation of $\mathrm{KB}$ acceptors by $95.6 \%$, while the other 4.4\% was caused by other factors which is not researched. The factors related to family planning acceptors are attitude $(p=$ $0,000)$, support of health workers $(p=0.002)$, and husband support $(p=0.004)$. These factors are directly related to the participation of family planning acceptors. For women of childbearing age, they can choose the type of contraception that suits their purpose in family planning, which is delaying, spacing or stopping pregnancy. This can give the ma $\mathbf{n}$ faat in improving reproductive health and family welfare.
\end{abstract}

\section{Keywords-Family, Vilage Community, Tasikmalaya}

\section{INTRODUCTION}

The problem of population is one of the problems faced by developing countries, including Indonesia. One of the population problems facing Indonesia is the high population growth rate. The 2018 population census shows that the total population of Indonesia is around 265.02 million women, with 133.87 inhabitants. But this number has decreased the population from 2014 (252, 12 million people) until 2018.
The population in West Java is the largest population in Indonesia of 48.68 million. This is clearly seen that the population from year to year always increases [1,2].

Indonesia is a country with a high population. Indonesia is the fourth country with the most population in the world. The population of Indonesia from year to year continues to increase. According to data from the Central Statistics Agency (BPS) in 2017, there were 258.2 million people in Indonesia in 2015, 261.1 million in 2016 and 264 million in 2017[3].

The Central Statistics Agency (BPS) in August 2010 stated that Indonesia's population was $237,556,363$ people consisting of $119,507,600$ men and 118,048,783 women, with a population growth rate of $1.49 \%$ per year. This population growth certainly has significant implications for the economic development and welfare of the State. From this description, the government took an anticipatory step to reduce the high rate of population growth by forming a body that is specifically and specifically responsible for controlling population growth in Indonesia, namely the National Family Planning Coordinating Board (BKKBN) [4].

The National Family Planning Program has an important contribution in efforts to improve the quality of the population in Indonesia [5]. The results of the 2017 family data collection showed that nationally the number of Active KB participants was 23,606,218 participants, and the number of fertile age couples (PUS) was 37,338,265 participants, so the level of participation using KB from all PUS was $63.22 \%$. Those who use the MKJP KB in 2017 are only 17, 45\% and those who use the Non MKJP are $82.55 \%$ and West Java Province ranks 12th in terms of the prevalence of EFA of FP participants [6]. 
Based on data from the Republic of Indonesia Ministry of Health, it shows that in 2017 in Indonesia active family planning participants with IUD use were 397,996 (7.75\%), MOW was 194,636 (3.41\%), MOP was 39,843 (0.70\%), condoms were $65,390(1.14 \%)$, implants of 471,979 (8.26\%), injections $4,128,115(48.56 \%)$, pills of 993,255 (7.39\%). In West Java according to (Ministry of Health of Republic of Indonesia, 2017) the number of PUS is $1,545,324$ and the number of PUS active KB participants is $1,058,887$ and those using IUD 85,534 (8.17\%), MOW 3,319 (36,138\%), MOP $5,785(0,55 \%), 7,655(0.72 \%)$ condoms, implants 60,194 (5.68\%), 650,390 injections (5.68\%), pills 209,027 (19.74\%) $[7,8]$.

According to the theory of Green there are three factors that determine the behavior of a person, the predisposing factors (predisposing factors), factor support (enabling factors), $\mathrm{d}$ an factors (reinforcing f actors). These three factors influence the behavior of community participation in family planning [9].

Based on the above background the authors are interested in conducting research in order to analyze "Factors Related to the Participation of Family Planning Acceptors in the Community of Sumulagung Village, Cikunir Village, Tasikmalaya Regency in 2019".

\section{METHODS}

This type of research is quantitative with a cross sectional descriptive method, that is, a study that studies the relationship between the free variables of $\mathrm{KB}$ acceptors participation with the dependent variable, namely attitudes, service access, health facilities, support of friends, husbands, and family. The data used are using primary data with instruments in the form of questionnaires. The population is all women of childbearing age in Sumulagung village with 106 fertile women with a total sample of 49 fertile women, with a purposive sampling technique. The criteria for inclusion are as follows: women aged 15-49 years old, using contraception, are willing to be respondents, can read and write, it is still possible to get pregnant (menstruation). The analysis used is the analysis using the Structural Equation Modeling (SEM) method.

III. RESULTS

TABEL I. CHARACTERISTICS OF RESPONDENTS

\begin{tabular}{|c|c|c|c|}
\hline No & Characteristics of Respondents & Frequency (f) & Percentage (\%) \\
\hline \multirow[t]{4}{*}{1} & Age & & \\
\hline & $<20$ years old & 1 & 2.0 \\
\hline & $20-35$ years old & 31 & 63.3 \\
\hline & $>35$ years old & 17 & 34.7 \\
\hline \multirow[t]{5}{*}{2} & Education & & \\
\hline & Elementary school & 10 & 20.4 \\
\hline & Middle School & 25 & 51.0 \\
\hline & High school & 13 & 26.5 \\
\hline & PT & 1 & 2.0 \\
\hline \multirow[t]{3}{*}{3} & Working Mothers & & \\
\hline & Work & 22 & 44.9 \\
\hline & Does not work & 27 & 55.1 \\
\hline \multirow[t]{6}{*}{4} & Number of children & & \\
\hline & Have not had & 2 & 4,1 \\
\hline & One & 12 & 24.5 \\
\hline & Two & 18 & 36.7 \\
\hline & Three & 13 & 26.5 \\
\hline & Four & 4 & 8.2 \\
\hline \multirow[t]{3}{*}{5} & Income & & \\
\hline & $\geq$ Rp. 2.1 Million & 21 & 42.9 \\
\hline & $<2.1$ million & 28 & 57.1 \\
\hline \multirow[t]{3}{*}{6} & Yankes's place & & \\
\hline & Puskesmas / Hospital & 12 & 24.5 \\
\hline & Private Clinic / Doctor / Midwife Practice & 37 & 75.5 \\
\hline \multirow[t]{3}{*}{7} & Mileage Fasyankes & & \\
\hline & Close & 37 & 75.5 \\
\hline & Far & 12 & 24.5 \\
\hline \multirow[t]{3}{*}{8} & Transportation costs & & \\
\hline & Cheap & 26 & 53.1 \\
\hline & Expensive & 23 & 46.9 \\
\hline \multirow[t]{3}{*}{9} & Access Print Media Information & & \\
\hline & Newspaper & 8 & 16.3 \\
\hline & Poster / Baligo & 41 & 83.7 \\
\hline \multirow[t]{4}{*}{10} & Access to Electronic Media Information & & \\
\hline & The TV & 15 & 30.6 \\
\hline & Radio & 3 & 6.1 \\
\hline & Internet & 31 & 63.3 \\
\hline
\end{tabular}




\begin{tabular}{|c|l|c|c|}
\hline No & Characteristics of Respondents & Frequency (f) & Percentage (\%) \\
\hline 11 & Access information from relatives & & \\
\hline & Family & 21 & 42.9 \\
\hline & Friends / Neighbors & 19 & 38.8 \\
\hline & Health workers & 9 & 18.4 \\
\hline 12 & Knowledge & & \\
\hline & Good & 41 & 83.7 \\
\hline & Enough & 8 & 16.3 \\
\hline 13 & Attitude & 39 & 79.6 \\
\hline & Support & 10 & 20.4 \\
\hline & Does not support & & \\
\hline 14 & Health workers & 40 & 81.6 \\
\hline & Support & 9 & 18.4 \\
\hline & Does not support & & \\
\hline 15 & Husband's Support & 38 & 77.6 \\
\hline & Support & 11 & 22.4 \\
\hline & Does not support & & 83.7 \\
\hline 16 & KB Participation & 41 & 16.3 \\
\hline & Corresponding & 8 & $\mathbf{1 0 0 . 0}$ \\
\hline & It is not in accordance with & $\mathbf{4 9}$ & \\
\hline & Total & & \\
\hline
\end{tabular}

Based on table 1 the results of research on the characteristics of respondents seen from the age of 31 fertile women $(63.3 \%)$ aged $20-35$ years, while those aged $>35$ years were 17 fertile women (34.7\%). Judging from the education level, there were 25 junior high school graduates $(51 \%)$, while only 1 fertile women college $(2 \%)$. On average fertile women did not work as many as 27 FERTILE WOMEN (55.1) while those who worked 22 fertile women (44.9\%). The highest number of children (parity) of two children is 18 fertile women $(36.7 \%)$, three children are 13 fertile women
( $26.5 \%)$, one child is 12 fertile women $(24.5 \%)$, four children are 4 fertile women $(8,2 \%)$, and not having 2 children $(4.1 \%)$.

The highest number of health services in private clinics / doctor's practice / midwives close distance is 37 fertile women $(75.5 \%)$. Access to obtain information about family planning through the most printed media on posters / baligo was 41 fertile women $(83.7 \%)$, most electronic media internet was 31 fertile women $(63.3 \%)$, most family information was 21 fertile women $(42.9 \%)$ ) . for fertile women knowledge, 41 fertile women $(83.7 \%)$ are good and supportive attitudes towards family planning programs are 39 (79.6\%) support.

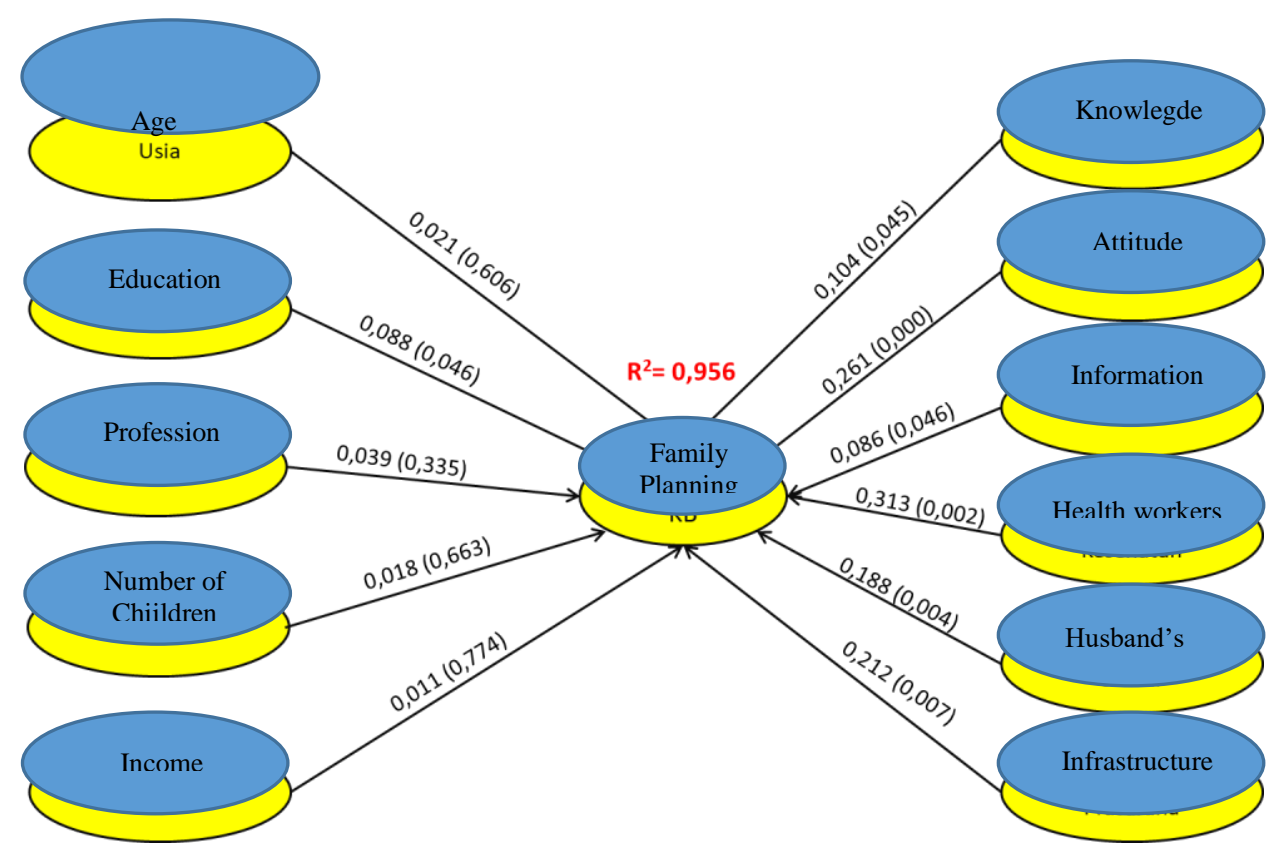

Fig. 1. SEM analysis results 
Based on the results of the analysis above, it is known that the analysis of factors related to the participation of $\mathrm{KB}$ acceptors obtained an $\mathrm{R}^{2}$ value of 0.956 meaning that all factors analyzed can explain the participation of $\mathrm{KB}$ acceptors by $95.6 \%$, while the other $4.4 \%$ is caused by other factors that are not researched. The factors related to family planning acceptors are education $(\mathrm{p}=0.046)$, knowledge (0.045), attitude $(\mathrm{p}=0.000)$, access to information $(\mathrm{p}=$ $0.046)$, support of health workers $(\mathrm{p}=0.002)$, husband support $(\mathrm{p}=0.004))$, and infrastructure or health facilities ( $p$ $=0.007)$. These factors are directly related to the participation of family planning acceptors.

\section{DISCUSSION}

A. Attitudes and participation of family planning acceptors

Based on the research results in Sumulagung Village Cikunir Village, Tasikmalaya Regency in 2019, the result was $P$ value $0,000<0.05$, which means there is a relationship between family attitudes and participation. This is consistent with the theory that attitude is a reaction or response that is still closed from someone to a stimulus or object. Attitude is not an action or activity but is a predisposition to the action of a behavior. That attitude is still a closed reaction, not an open reaction or open behavior. Attitude is a readiness to react to objects in a particular environment as an appreciation of the object $[10,11]$.

Attitudes arise based on the evaluation process in individuals who give conclusions about the stimulus in the form of good value, negative, positive, pleasant not pleasant. The attitude structure consists of three mutually supporting components namely cognitive, affective, and conative components. The cognitive component is a representation that is believed by individuals to have an attitude, the affective component is a feeling that involves emotional aspects, and conative is an aspect of a certain tendency to behave in accordance with the attitudes of a person [12].

This is in accordance with the 2015 Narulloh research in Surakarta which stated the Chi-Square test results obtained $\mathrm{p}$ value $=0.003<0.05$ so that it can be concluded that there is a relationship between attitudes with the participation of Fertile Age Couples (PUS) in KB. From table 9 known the value of the Prevalence Ratio (RP) of 2.80 which means that respondents who have a negative attitude about family planning programs, have a 2.8 times greater risk of not having family planning compared to respondents who have a positive attitude (95\% CI: 1.40- 5.58) [13].

A person's attitude is influenced by aspects of knowledge that contain positive and negative aspects of a thing. When people see family planning programs more positive aspects than negative aspects, and positive aspects are more important than negative aspects, then a positive attitude towards family planning programs will grow. Conversely, if someone sees a family planning program more negative aspects than positive aspects, then a negative attitude will emerge $[5,13,15]$.

\section{B. Family planning support and participation}

Based on the research results in Sumulagung Village Cikunir Village, Tasikmalaya Regency in 2019, the result was $\mathrm{P}$ value $0.002<0.05$, which means that there is a relationship between the support of officers and family planning participation. This is in accordance with the theory which states that the duties of a family planning officer in the field are motivating, giving explanations, giving advice, as a companion, as a monitor and partner in problem solving, so that becoming a KB officer must have complete, correct and honest information, willingness and interest to be a counseling officer, patient, friendly and open to respect the opinions of others, can foster relationships and find client confidence and no less important to have skills in communicating / providing counseling so that it can help clients understand themselves, the obstacles that exist in themselves and when needed assist in the decision making process through a variety of objective considerations. Health workers play an important role in the final stages of the selection and use of contraceptives, because prospective acceptors who are still hesitant in using contraceptives finally decide to use contraception after receiving encouragement from health workers because health workers are the parties who take the role in the final stages of the selection process and contraceptive use [16].

.The results of this study are in line with the 2019 Puspita dewi research in jember which stated that the majority of respondents with the role of passive officers were 214 respondents $(99 \%)$ did not participate in the family planning program and respondents with the role of active officers were 36 respondents $(22 \%)$ participated in the program $\mathrm{KB}$. The results of data analysis using logistic regression tests resulted in a significance of $0,000(\mathrm{p}<0.05)$, which is the influence of the role of family planning officers on the participation of male EFAs in the KB program. This is due to the lack of family planning staff and the lack of available special infrastructure for male family planning so that the implementation of counseling is limited so that respondents assume that the role of family planning staff is passive $[5,15$ 16].

It can be concluded that health workers have an important role in increasing family planning participation through motivating, giving explanations, giving advice, as a companion, as a monitor and partner in solving family planning problems. So that people want to participate in family planning and use contraception in accordance with the purpose of family planning.

C. Husband support and family planning participation Based on the results of the study, it was found that in Sumulagung Village Cikunir Village, Tasikmalaya Regency in 2019 the relationship between husband support and family participation was $P$ value $0.004<0.05$ meaning that there was a relationship between husband support and family participation. Husband's support is the encouragement given by the husband in the form of moral and material support in terms of realizing a plan which in this case is the selection of 
contraception (Friedman (1998) in Prasetyawati, 2011). Support makes the family able to carry out its functions, because family members are supposed to provide mutual support and pay attention to each other's wife's health conditions and needs. According to Friedman (1998) in Prasetyawati (2011), husband's support consists of 4 forms, namely informational support, assessment, instrumental, and emotional [16,17].

According to Suryono (2008), husband's support in family planning can be demonstrated by helping choose contraception in accordance with the wishes and conditions of his wife, use contraception correctly, seek help if side effects or complications occur after IUD installation, take the wife to the health service for re-control, help find alternatives if the IUD is proven unsatisfactory and is willing to replace the wife if the wife's condition makes it impossible to use contraception [20].

Similar research results are the results of a study conducted by Sulastri in 2012 in Bergas which stated that respondents who received support were slightly higher than those who did not provide support at 50.6\% and most respondents had low interest of $76.4 \%$. Statistical test results with Chi-Square test obtained $p$ value of $(0.006)<\alpha(0.05)$. Based on the results of statistical tests that there is a significant relationship between husband support and maternal interest in using IUD contraception in Bergas [21].

It can be concluded that the husband's support has the role of increasing family planning participation through helping to choose contraception in accordance with the wishes and conditions of his wife, using contraception correctly, seeking help in the event of side effects or complications after IUD installation, taking the wife to the health service for recontrol,

help find alternatives if the IUD is proven unsatisfactory and is willing to replace the wife if the wife's condition is not possible

\section{CONCLUSION}

Based on the results of the analysis above, it is known that the analysis of factors related to the participation of $\mathrm{KB}$ acceptors obtained an $\mathrm{R}^{2}$ value of 0.956 meaning that all factors analyzed can explain the participation of $\mathrm{KB}$ acceptors by $95.6 \%$, while the other $4.4 \%$ is caused by other factors that are not researched. The factors related to family planning acceptors are attitude $(\mathrm{p}=0,000)$, support of health workers $(p=0.002)$, and husband support $(p=0.004)$. These factors are directly related to the participation of family planning acceptors.

\section{SUGGESTION}

Referring to the results of the study, some things that are expected to be input are to increase family planning participation, it requires an active role from all parties, especially the provision of information about the appropriateness of contraceptive selection with the aim of family planning by health workers

\section{REFERENCES}

[1] Basic Health Research, Indonesian Ministry of Health's Research and Development Agency. 2018.

[2] Health Research and Development Agency, "2013 Basic Health Research," Ris. Healthy. Basic 2013, 2013.

[3] B. P. Statistics, Statistics Indonesia. Central Jakarta: Central Statistics Agency, 2017.

[4] K. Irianto, Family Planning Services. Bandung: Alfabeta, 2014.

[5] M. M. AM Rosliza, "Male Participation and Sharing of Responsibility in Strengthening Family Planning Activities in Malaysia," Malaysian J. Public Heal. Med., Vol. 10, no. 1, pp. 23 27, 2010.

[6] BKKBN, Regulation of the Head of the National Population and Family Planning Agency Number 24 of 2017 concerning Postpartum Family Planning Services and Post-Miscarriage. Jakarta: BKKBN, 2017.

[7] The Indonesian Ministry of Health, "Data and information center," South Jakarta, 2014.atan, 2014.

[8] The Indonesian Ministry of Health, "Indonesia's Health Profile in 2017," Jakarta, 2018.

[9] S. Notoatmodjo, Health Promotion Theories and Applications. Jakarta: Rineka Cipta, 2005.

[10] S. Notoatmodjo, "Health Communication," Health Promotion Theories and Applications. 2010

[11] Sinta Fitriani, Health Promotion. Yogyakarta: Graha Science, 2011.

[12] L. V. Adistie F, Maryam NNA, "Health Cadre Knowledge about Early Detection of Malnutrition in Toddlers," J. Apl. Science and Technology for the People, 2017.

[13] Nasrulloh et al, "Relationship between Knowledge, Attitude, and Family Support with the Participation of Fertile Age Couples in family planning in the work area of Purwosari Public Health Center in Surakarta City," Muhammadiyah Surakarta University, 2015.

[14] A. Glasier and A. Gebbie, "Family Planning/Contraception," in International Encyclopedia of Public Health, 2016.

[15] D. W. M. b A, John A. Ballweg, "Family planning method change and dropouts in the Philippines," Biodemography Soc. Biol., vol. 21, no. 1, pp. 88-95, 2014, doi: https://doi.org/10.1080/19485565.1974.9988092.

[16] A. D. Budiadi N, Wijayanegara H, "Knowledge, Husband's Support and Support of Health Workers in Acceptors of IUDs and NonIUDs in the Work Area of the Ibrahim Haji Community Health Center in Bandung," J. Akad. Midwifery Medica Obgyn, 2011.

[17] Puspita S, "Wife's Support, The Role of Family Planning Officers in Increasing Men's Participation in Family Planning," Arter. J. Health Sciences., Vol. 1, no. 1, pp. 43-49, 2019.

[18] S. M. M. N. Muhammad Ali Sodik, "The Role Of Health Promotion And Family Support With Attitude Of Couples Childbearing Age In Following Family Planning Program In Health," J. Glob. Reasearch Public Heal., vol. 2, no. 2, 2017, doi: https://doi.org/10.30994/jgrph.v2i2.105.

[19] Prasetyawati AE., Public Health. Yogyakarta: Nuha Medika, 2011.

[20] Suryono B.A, Men's Participation in Reproductive Health. http://prov.bkkbn.go.id., 2008.

[21] Sulastri, "Husband's Support with Mother's Interest in Using the IUD in Bergas," 2012.

[22] Health Research and Development Agency, "2013 Basic Health Research," Ris. Healthy. Basic 2013, 2013. 